\title{
ASSISTANCE OF CREATIVITY CHILDREN IN GROWING AWARENESS OF THE 5M PROTOCOLS IN THE TIME OF COVID 19
}

\author{
Arief RUSLAN ${ }^{*}$, Laksmi RACHMARIA ${ }^{2}$, Jeanie ANNISSA ${ }^{3}$, Ahmad TONI ${ }^{4}$, \\ Geri SURATNO ${ }^{5}$, and Koen HENDRAWAN ${ }^{6}$ \\ 1,2,3,4,5 Faculty of Communication Studies, Budi Luhur University, Indonesia \\ ${ }^{6}$ Faculty of Economics and Business, Budi Luhur University, Indonesia \\ *arief.ruslan@budiluhur.ac.id
}

\begin{abstract}
The increase in the corona or covid 19 pandemic in Indonesia is no longer something to be taken lightly. With many cases of spread and addition in South Jakarta the most recorded in the Kebayoran Lama area. It is possible that many people still do not understand the importance of the 5M concept as a protocol to break the chain of spreading the virus. This community service is carried out for TKAU children in Ulujami, South Jakarta. This segmentation of the selection of children as a basis for education and understanding the importance of $5 \mathrm{M}$ is carried out from an early age. Using the mixing methodnamely, the form of explanation through lectures and drawing practice, the service process went very well. Some forms of understanding about $5 \mathrm{M}$ by children by means of adaptive communication such as using language styles that are easy to understand. The form of creativity through drawing activities also plays an important role in building an atmosphere that is not rigid, and even becomes an exciting part of its own. Therefore, with this community service process with an understanding style, children can be understood, reached, and practiced carefully.
\end{abstract}

Keywords: Covid 19, Early Age, Creativity, 5M, Protocol

\section{BACKGROUND}

The fluctuation of the Corona Virus or COVID 19 pandemic in the country, has been going on for at least two years since it first appeared in 2020 in Indonesia. This unresponsiveness to this pandemic is indeed a problem in itself, that in the early days of the news about the existence of a highly contagious disease discovered by the Chinese government in Wuhan, the Indonesian government had stated that this "country" was free from the pandemic. It is very ironic when this statement makes this case inevitable, soaring, even taking many victims. Saragih (2020) reported through thought-rakyat.com showing that the government had taken lightly about the pandemic that occurred at that time. So with ignorance about the phenomenon of events in China, which is very large, it makes a spike in cases in Indonesia.

The spike in cases of this pandemic is not only happening in Indonesia, but superpower countries like America are also affected. It can be said that the corona virus is a disease that is very difficult to cure and has time for research to treat it. Recovery and the search for a vaccine really takes time, so people need to be patient and follow the rules to break the chain of spread. Many people who still lack awareness of complying with health protocols are a part that deserves attention (Pasaribu, et al., 2021; Rachmadi, et al., 2021). Ignorance sometimes builds opinion on distrust of this pandemic is also a problem in itself.

In January 2021, new cases of COVID-19 spread in the Jakarta area. Haryanti (2021) revealed " Head of Disease Prevention and Control of the DKI Jakarta Health Service, Dwi Oktavia through a written statement, conveyed that new cases of Covid-19 in Jakarta were spread in all sub-districts in the capital, 44 sub-districts to be exact ". Of all the reported cases, he stated that the most additions occurred in the Kebayoran Lama area with 127 cases. This shows that there is still a chain of spread that occurs in the region requires an understanding of the pandemic that is still vicious and the need for attention from the community (Hestiana, et al., 2021; Abidin, et al., 2021; Aulia, et al., 2021).

The importance of understanding to break this chain may not just be through messages in the media, a group around, or just done on the basis of information being spread through loudspeakers. Ubaidillah (2021) reveals the need for actions that must provide information to be understood by everyone, especially children who do not understand much about $5 \mathrm{M}$. Children can play an important role in the new spread in society. Ignorance and even an indifferent attitude can result in the chain of distribution being rebuilt, so awareness and guidance are urgently needed regarding the pandemic problem that is happening in this country.

Seeing this problem, the researchers tried to provide community service in the Ulujami area, South Jakarta in collaboration with the local urban village. This community service aims to provide assistance and provide information about the importance of understanding 5M, namely washing hands, wearing masks, maintaining distance, staying away from crowds, and reducing mobility. This assistance is not only through lectures and explanations, but also by using the form of children's creativity practices to provide an atmosphere and rebuild morale (Boden, 2004). The targets for this service are children from the Ulujami Al-Quran Education Park, South Jakarta. Through this community service to see how the correspondence understands about $5 \mathrm{M}$ awareness? and explore whether creativity plays a role in this awareness? 


\section{METHODS}

This community service activity was carried out at the Ulujami Al-Quran Education Park (TKAU), South Jakarta, which was coordinated by the Ulujami sub-district, Rukun Tetangga (RT) 009/005, Proyo Sunaryo. To be able to run in good conditions, this implementation is carried out with health protocols in accordance with government regulations and also the foundation of the $5 \mathrm{M}$. The preparation for this implementation was assisted by Ubaidillah as the children's supervisor and also who has responsibility for TKAU. The tools prepared by the implementing coordinator as a form of $5 \mathrm{M}$ are hand washing tools such as soap, water, hand sanitizer or antiseptic hand sanitizer, and masks. Participants who take part in this implementation are also limited according to the available space and the distance between the participants, which is 15 people and every 1 meter distance between participants.

The form of guidance is carried out with lectures that are easily understood by participants who are segmented by children, so that information can be easily understood and good communication is established. The provision of material through this lecture was carried out for 30 minutes, and was followed by a question and answer session and practice of understanding for 10 minutes. The material provided is about the $5 \mathrm{M}$ protocol, namely, a) hand washing; b) wear a mask; c) keep your distance; d) stay away from crowds; and e) reduced mobility.

In the creativity stage, the implementer prepares several instruments/tools, namely pencils, erasers, paper, and road boards which will be given to each participant. This process is carried out for 30 minutes, such as providing stages about making hijaiyah letters using stationery. Next, the processed images are collected to be presented by the children as part of the procession to build a pleasant atmosphere in the implementation of this community service.

This form of creativity is to show and map the sustainability of the implementation which also builds awareness not only about $5 \mathrm{M}$ awareness, but also the enthusiasm of the participants. Thus, the implementer can provide easy information as well as present an exciting implementation.

\section{RESULTS AND DISCUSSION}

This community service was carried out for the first time by conducting lectures by several implementing members. This lecture provides an understanding of $5 \mathrm{M}$ in a relaxed and easy-to-understand way for children. The choice of this relaxed style is to build good communication and enter into the segmentation of the communicant. The implementation process of the lecture by the executor was carried out in an Al-Hikmah Mosque by sitting relaxed in the courtyard of the mosque. The place used was in accordance with the direction of Ubaidillah as the teacher and also the supervisor of the TKAU children. Besides that, through community service in this yard, it builds a relaxed style of education so that it doesn't stress the children.

The explanation of $5 \mathrm{M}$ by implementing members can be described as follows, first is wearing a mask (M1), which provides participants' understanding of the form, use , and when to use this mask, by showing how to wear it, its use, and when to use this mask. should be disposed of and where and how to dispose of it. The second is hand washing (M2) , explaining how to wash hands properly. This explanation is also carried out in a simple way as the most accessible and affordable tool for them. In addition, it also explains when and where this hand washing activity is carried out.

Furthermore, in the third explanation is keep your distance (M3). The executor explained about how to maintain a good distance. This matter of keeping a distance is also communicated according to the way the child thinks, namely by practicing it so that it is easy to understand. Regarding the rules for going out of the house, they are also explained according to their criteria, namely how it is important to leave the house and the procedure for leaving the house if it is in conditions that are highly required.

The fourth is about the theme of staying away from the crowd (M4), which describes the behavior of a NDA were also asked to stay away from the crowd when outside the home. It is important to remember that the more and often you meet people, the higher the chance of being infected with the corona virus. The fifth is the issue of reducing mobility (M5) which describes the forms of mobility that is not important, important, and the need to think why should reduce activities that are not necessary and impacts that occur when it is violated, as is likely to pass on the family and friends in the neighborhood.

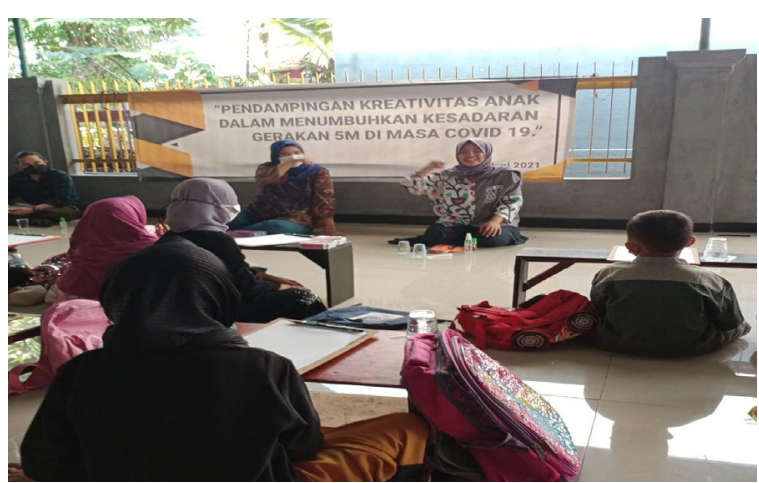

Picture 1 . The executor explains about 5M to TKAU

In this lecture session, the executor got several models of understanding by participants, namely TKAU children that could be taken, table 1 .

Understanding the theme of reducing mobility (M5) seems to give difficulties in understanding it. The word mobility is a word that is quite difficult to understand both by definition. For TKAU children, this word is often a big enough question to understand. Several questions often occur, such as about the definition and examples. Even the participants also asked the difference between the M4 and M5. 
Table 1 . The understanding of childresn about $5 \mathrm{M}$

\begin{tabular}{lccccc}
\hline \multicolumn{1}{c}{ Name } & M1 & M2 & M3 & M4 & M5 \\
\hline Dina & V & V & V & V & - \\
Aliya & V & V & V & V & - \\
Mahardika & V & V & V & V & - \\
Ziyad & V & V & V & V & - \\
Raffa & V & V & V & V & - \\
Jasmine & V & V & V & V & - \\
Imran & V & V & V & V & - \\
Riyad & V & V & V & V & - \\
Nadya & V & V & V & V & - \\
Alya & V & V & V & V & - \\
Dian & V & V & V & V & - \\
Latif & V & V & V & V & - \\
Fatimah & V & V & V & V & - \\
Kiara & V & V & V & V & - \\
Faris & V & V & V & V & - \\
\hline
\end{tabular}

Of course this is a challenge for implementers to be able to provide knowledge of the word form. The implementer tries to provide an understanding that is easy to understand, remember, and absorb by children, so that the form of $5 \mathrm{M}$ activities launched by the government as part of breaking the chain of this pandemic goes well by children.

Fundamentally, the word M5 provides passages that are very difficult for children to digest. At least, an explanation of the definition of mobility should be given in a good way by the community. Good and easy-to-digest communication should indeed be an important goal in sending information so that the recipients can understand it clearly. For TKAU children, the M5 theme is considered a little confusing because the first is a word that is not easily absorbed by them, and the second is the closeness between the M5 and M4 themes which are considered very synonymous by definition.

Through these lectures and explanations, the TKAU children were very enthusiastic and understood what the executor explained. Some children can also provide answers to questions and how to practice the $5 \mathrm{M}$ form that has been explained. In addition, these TKAU children can also provide examples to their friends and their mentor, Ubaidillah, about how to apply $5 \mathrm{M}$ to themselves and to the community (friends).

Through the analysis that the implementer got in the lecture process, the TKAU children quite understood the explanation given. In addition, the occurrence of feedback ( feedback ) by children such as questions, and enthusiasm to practice what was asked by the executor as one of the activities in the implementation of this community service. Broadly speaking, implementation with appropriate communication with segmentation can provide good and appropriate information. Communication becomes smoother and can be understood and acted upon by the communicants.

In the second stage, the implementation of children's creativity is carried out through the drawing process. The implementation attributes that have been provided such as this drawing tool are a good support. As that complete attributes build children's activities in shaping their creativity. Thus the process for processing images through these attributes can be used in accordance with the conditions and expectations of the implementers of community service.

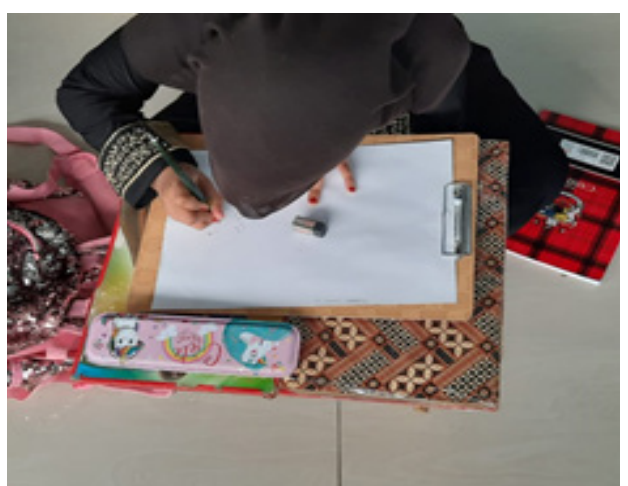

Picture 2. The process of processing the creativity of TKAU children

In this drawing process, the implementers provide material that is in accordance with the educational criteria at TKAU. Ubaidillah said that TKAU in addition to learning about religion such as learning to read the Koran, memorizing the hijaiyah letters, but also requires writing about the letters. So that the executor provides learning how to be creative in drawing hijaiyah letters with a good drawing style or according to the wishes of the children.

In the drawing procession, several obstacles occur in it, namely, difficulties in forming or drawing hijaiyah letters which are considered as new learning, or definitively, as a form of creativity that has just been practiced. So even though they understand the forms of the hijaiyah letters, in forming a new image model it becomes another separate part.

In the drawing process, the implementer not only teaches in forming hijaiyah letters into creative images, but also builds sustainable community service that is more dynamic and relaxed in accordance with TKAU activities. It was shown that the children were very happy and sometimes jokes were made to other participants. So for implementers, this creative process plays an important role in community service which is presented with the mixing method, namely lectures and practice.

At the end of this drawing procession, the executor asks for the results of the depiction of the hijaiyah letters to be collected. At this stage the participants were also asked to explain the pictures they made. The organizers saw that the TKAU participants were very happy and excited, there were even some children who were late in collecting and asked to finish them first. So that children's enthusiasm in the drawing process does not only form creativity, but also builds morals for the fun of drawing.

\section{Discussion}

$5 \mathrm{M}$ is a protocol that is the obligation of the community as a form of breaking the chain of the covid 19 pandemic. The provision of this information is of course a 
special concern by the government how it can be given in its entirety, easily absorbed, and understood not only from adults, but also from children. In fact, children are not part of those who often forget the protocol, but they often do not understand the information given through words that are very difficult to understand. Moreover, some parents may not be able to explain in detail about these themes.

Building communication with children is an important part and a special form, this is due to the understanding of children who still have not absorbed exclusive words. Communicative action is not just providing information to the public about a message that must be taken, but also good communication is how this message is received, understood, and carried out according to the information. Thus, the success of appropriate information is carried out through communication between communicators who give good messages to their communicants. Of course, this communication is thirsty to see the social and culture of a person or region.

\section{CONCLUSION}

This activity in community service aims to provide an understanding of health protocols for a very vicious pandemic in Indonesia. By using the $5 \mathrm{M}$ protocol, it must be the basis for breaking the chain of the spread of the covid 19 virus. The explanation of the $5 \mathrm{M}$ protocol must be communicated early, but the form of communication must be in accordance with the segmentation of the audience. The procession went very smoothly which was shown by the understanding of the participants and their enthusiasm for this implementation.

Relaxed style with mixing methods such as lectures and drawing practice, providing a more harmonious and fun atmosphere. Of course, protocol practice is also delivered in a simple and easy-to-understand way. Thus the communication process on this segmentation can be accepted and practiced by the community. Thus, the fabric of communication becomes an important role as a medium of information to the public. Segmentation is also an important concern that communication will not be established if there is a "wall" that closes the communication line.

\section{ACKNOWLEDGEMENT}

For the successful implementation of this community service, the executor expresses his deepest gratitude to the chairman of the Rukun Tetangga 009/05, Mr. H. Proyo Sunaryo, who has given the opportunity to implement it. Do not forget to also thank Mr. Ubaidillah and the TKAU teachers who were very supportive and gave good responses, as well as good coordination to achieve this activity.

\section{REFERENCES}

Abidin, Z., Yanti, A., Zulfayanto, I., Rasid, M., Ismiyanti, N., Fitrianingsi, N., and Bilkist, ZK (2021). Peningkatan Kualitas Kesehatan Masyarakat untuk Pencegahan Penyebaran Covid-19 di Masa Pandemi. Jurnal Pembelajaran Pemberdayaan Masyarakat (JP2M), 2(1), 41-46.

Aulia, G., Fahriati, AR., Ratnaningtyas, TO., Utami, SM., Pratiwi, RD., Ismaya, NA., and Sabrina, PA. (2021). Edukasi Pencegahan Covid-19 Dengan Protokol Kesehatan 5M dan Pentingnya Multivitamin di Masa Pandemi Covid-19. JAM: Jurnal Abdi Masyarakat, 2(1), 133-140.

Boden, MM. (2004). The Creative Mind: Myths and Mechanisms. Routledge, New york.

Haryanti, R. (2021, January 8). Kasus Baru Covid-19 Tersebar di Seluruh Kecamatan Jakarta, Terbanyak di Kebayoran Lama. Kompas. https://megapolitan. kompas.com/read/2021/01/08/19160611/kasusbaru-covid-19-tersebar-di-seluruh-kecamatanjakarta-terbanyak-di

Hestiana, S., Sarani, R., Setiana, C. R., Nurlaila, E., \& Aldiansyah, D. (2021). Upaya Menerapkan 5m Melalui Peran Anak-Anak Sejak Dini Dalam Masa Pandemi Covid-19. Prosiding Dedikasi: Pengabdian Mahasiswa Kepada Masyarakat, 1(1), 167-172.

Pasaribu, VLD., Syafei, AN., Farhan, A., Aufaizah, A., Irani, C., \& Firtiayani, SR. (2021). Pengaruh Displin Protokol Kesehatan Terhadap Pencegahan Penularan Virus Covid-19. Jurnal Abdimas Tri Dharma Manajemen, 2(2), 91-98.

Rachmadi, TR., Yuliyanto, W., \& Waluyo, A. (2021). Pemberdayaan Masyarakat Dalam Pencegahan Penularan COVID-19 Melalui Sosialisasi Protokol Kesehatan di Pasar Rantewringin, Kecamatan Buluspesantren, Kabupaten Kebumen. JURPIKAT (Jurnal Pengabdian Kepada Masyarakat), 2(1), 126-136.

Sinuhaji, J. (2020 October 2). Sempat Disebut Indonesia Kebal Corona, Nyatanya Kini Kasus Covid-19 di Tanah Air Malah Kian Melonjak. Pikiran Rakyat. https://www.pikiran-rakyat.com/nasional/pr01793168/sempat-disebut-indonesia-kebal-coronanyatanya-kini-kasus-covid-19-di-tanah-air-malahkian-melonjak?page $=2$ 